\title{
Relationship between banana plant cultivation and stream macroinvertebrate communities
}

Relação entre cultivo de banana e a comunidade de macroinvertebrados aquáticos

Priscila Kleine ${ }^{1}$, Susana Trivinho-Strixino ${ }^{1}$ and Juliano José Corbi ${ }^{1,2}$

${ }^{1}$ Laboratório de Entomologia Aquática, Departamento de Hidrobiologia, Universidade Federal de São Carlos - UFSCar, CP 676, CEP 13565-905, São Carlos, SP, Brazil e-mail: strixino@ufscar.br; prikleine@yahoo.com

${ }^{2}$ Departamento de Hidráulica e Saneamento, Escola de Engenharia de São Carlos - EESC, Universidade de São Paulo - USP, Av. Trabalhador Sãocarlense, 400, CP 359,

CEP 13566-590, São Carlos, SP, Brazil

email: julianocorbi@yahoo.com.br

\begin{abstract}
Aims: The present study describes the influence of banana plant cultivation on macroinvertebrate communities of streams located in the southeastern region of São Paulo state in the Atlantic Forest (four located in areas of banana cultivation and four in preserved areas); Methods: Sampling was performed during October and November of 2005. The fauna was collected with Surber sampler and a D-aquatic net (both with mesh of $0.25 \mathrm{~mm}$ ) in rapids and backwaters. Simultaneously, an environmental characterization of each stream was made; Results: In total, 3,609 individuals were collected, distributed in 57 families, in which 45 were in forested streams and 46 in the banana plantation sites. Gripopterygidae, Perlidae, Leptophlebiidae, Leptoceridae, Helicopsychidae and Palaemonidae were abundant in forested streams, while Hydropsychidae, Chironomidae and Baetidae were abundant in the streams located in banana cultivation areas. Cluster analysis (UPGMA) with Simpson similarity measurement applied to the fauna of all streams evidenced the differences between forested and banana plantation streams. An analysis of similarity applied to both situations also pointed to significant differences $(\mathrm{p}<0.05)$ between the two areas; Conclusions: This agricultural activity, although did not influence species richness patterns, seems to influence the structure of macroinvertebrate communities in low order streams in the Atlantic Forest region.
\end{abstract}

Keywords: stream macroinvertebrates, lotic systems, banana cultivation, neotropical region, southeastern Brazil.

Resumo: Objetivos: $\mathrm{O}$ presente estudo analisou a influência do cultivo de banana sobre a comunidade de macroinvertebrados aquáticos de córregos localizados na região sul do Estado de São Paulo em áreas de Mata Atlântica (quatro em áreas com cultivo de banana e quatro localizados em áreas preservadas); Métodos: As coletas da fauna foram realizadas no período de outubro a novembro de 2005. Os macroinvertebrados foram coletados com amostrador tipo Surber e rede D, ambos com malha de $0,25 \mathrm{~mm}$ em áreas de corredeira e remanso; Resultados: No total, foram coletados 3609 macroinvertebrados pertencentes a 57 famílias, sendo 45 nos córregos florestados e 46 nos locais de cultivo da banana. Gripopterygidae, Perlidae, Leptophlebiidae, Leptoceridae, Helicopsychidae, e Palaemonidae foram mais abundantes nos córregos preservados, enquanto Hydropsychidae, Chironomidae e Baetidae foram mais abundantes nos córregos localizados em áreas de plantaçóes de banana. A diversidade, a riqueza e os índices comunitários responderam às características do uso de terra analisados. A análise de Cluster, utilizando-se UPGMA e Simpson como medida de similaridade, aplicada sobre a fauna de macroinvertebrados aquáticos, apontou para dois agrupamentos, sendo um localizado em áreas com cultivo de banana e outro localizado na área preservada. $\mathrm{O}$ teste de similaridade (ANOSIM) aplicado aos dois agrupamentos também apontou para diferenças significativas $(p<0,05)$ entre as duas áreas; Conclusóes: Esta atividade agrícola, apesar de apresentar pouca influencia para a riqueza de espécies, parece influenciar na estrutura da comunidade de macroinvertebrados de córregos de baixa ordem da regiáo da Mata Atlântica modificando os arranjos faunísticos.

Palavras-chave: macroinvertebrados de córregos, sistemas lóticos, cultivo de banana, região neotropical, sudeste do Brasil. 


\section{Introduction}

Aquatic ecosystems have been impacted by innumerable anthropic actions, such as agricultural activities, hydrologic alterations and pollution, causing modifications in the input of nutrients for these systems (Allan et al., 1997) and changes in the faunistic structure (Wood and Armitage, 1997; Pringle et al., 2000). However, the assessment and quantification of the effects caused by the anthropic impacts are difficult to evaluate because they can be confused with local, regional or temporal variations (Legendre et al., 2002; Townsend et al., 2004).

As aquatic organisms may integrate effects of perturbations, numerous studies have been proposed to use the stream macroinvertebrate community to validate the effects of different land uses. Some studies have demonstrated that these aquatic organisms can indicate impacts caused by organic enrichment (Wilhm, 1967; Brabec et al., 2004), reservoirs (Russel and Ward, 1988; Kleine and Trivinho-Strixino, 2005), sedimentation (Wood and Armitage, 1997), mining activities (Coutney and Clements, 2002) and agricultural activities, like sugar cane cultivation and pasture (Corbi and Trivinho-Strixino, 2008; Corbi et al., 2008) and soy and maize (Richards and Host, 1993). However, studies about the possible impacts of banana plant cultivation are rare.

Banana plant cultivation is different from others, since harvesting of the fruits is done manually and there is no cutting of the vegetation during the year (Embrapa, 2007). In this kind of culture, the maintenance of vegetal covering provides shading to the stream of the adjacent areas. Moreover, small amounts of pesticides are used when compared to other agricultural activities. For example, in banana cultivation, $0.31 \mathrm{~kg} / \mathrm{ha} /$ year of pesticides is used, while for sugarcane, $3.4 \mathrm{~kg} / \mathrm{ha} /$ year is used, and for apples, $49 \mathrm{~kg} / \mathrm{ha} /$ year (Castillo et al., 2006; Neves et al., 2002).

Another characteristic of this agricultural activity is that the majority of the cultivation of banana is located in areas of high declivity, as in the Atlantic Forest (Borges et al., 1997) that is considered one of the most impacted ecosystems in the world (Bibby et al., 1992) and therefore considered as one world-wide hotspot (Myers et al., 2000). This fact could bring about the high contamination of streams with toxic products, such as metals from fertilizers, which can come from the neighboring cultivated areas through a leaching process.

According to the Brazilian Federal laws, areas with riparian vegetation are classified as a permanent preservation area. In this context, knowledge about the relationship between banana plant cultivation and its influence on stream macroinvertebrate communities is of high importance for Brazilian sustainable development (Ometto et al., 2000; Roque and Trivinho-Strixino, 2001). In the present study, the influence of agricultural activity, in particular banana plant cultivation, on stream macroinvertebrate communities was evaluated.

\section{Material and Methods}

The study was undertaken in the Vale do Ribeira, São Paulo state, Brazil, in the Cananéia, Jacupiranga and Cajati municipalities (Figure 1), where banana cultivation is very intense.

The macroinvertebrates were collected in 8 streams (four located in areas of banana cultivation and four in preserved areas), during October and November of 2005 . The studied streams are located between the coordinates $24^{\circ} 50^{\prime}(\mathrm{S})-24^{\circ} 59^{\prime}$ (S) and $48^{\circ} 00^{\prime}(\mathrm{W})-48^{\circ} 59^{\prime} 5$ (W) (Table 1, Figure 2). Macroinvertebrates of each stream were collected using a D-frame aquatic net $(250 \mu \mathrm{m})$ (Merritt and Cummins, 1996) and a Surber sampler $(0.25 \mathrm{~mm})$ including riffle and pools areas, for 5 minutes, as recommended by Fontoura (1985). In each stream, 9 samples were collected. Samples were taken to the laboratory, washed in a sieve of $0.21 \mathrm{~mm}$ mesh, selected on an illuminated tray and fixed with 70\% alcohol. The taxonomic identification was achieved at the family level for most of them with the basis on the available published data (Brinckhurst and Marchese, 1991; Merritt and Cummins, 1996; Mariano and Froehlich, 2007; Souza et al., 2007; Calor, 2007; Lecci and Froehlich, 2007; Pinho, 2008; Azevedo and Hamada, 2008). Based on the study conducted by Corbi and Trivinho-Strixino (2006), family identification appeared to be good for monitoring the effects of different land uses on macroinvertebrate communities in low order streams.

In order to aid the evaluation of the integrity of the 8 streams, physical and chemical variables of the water were measured. Physical and chemical variables such as temperature, dissolved oxygen and electric conductivity were measured in situ, by using a Water Quality Checker device (Horiba).

\subsection{Data analysis}

There is no index correlating the macroinvertebrate communities and the local environment in the state of São Paulo, or any waterquality index using the macroinvertebrate fauna 


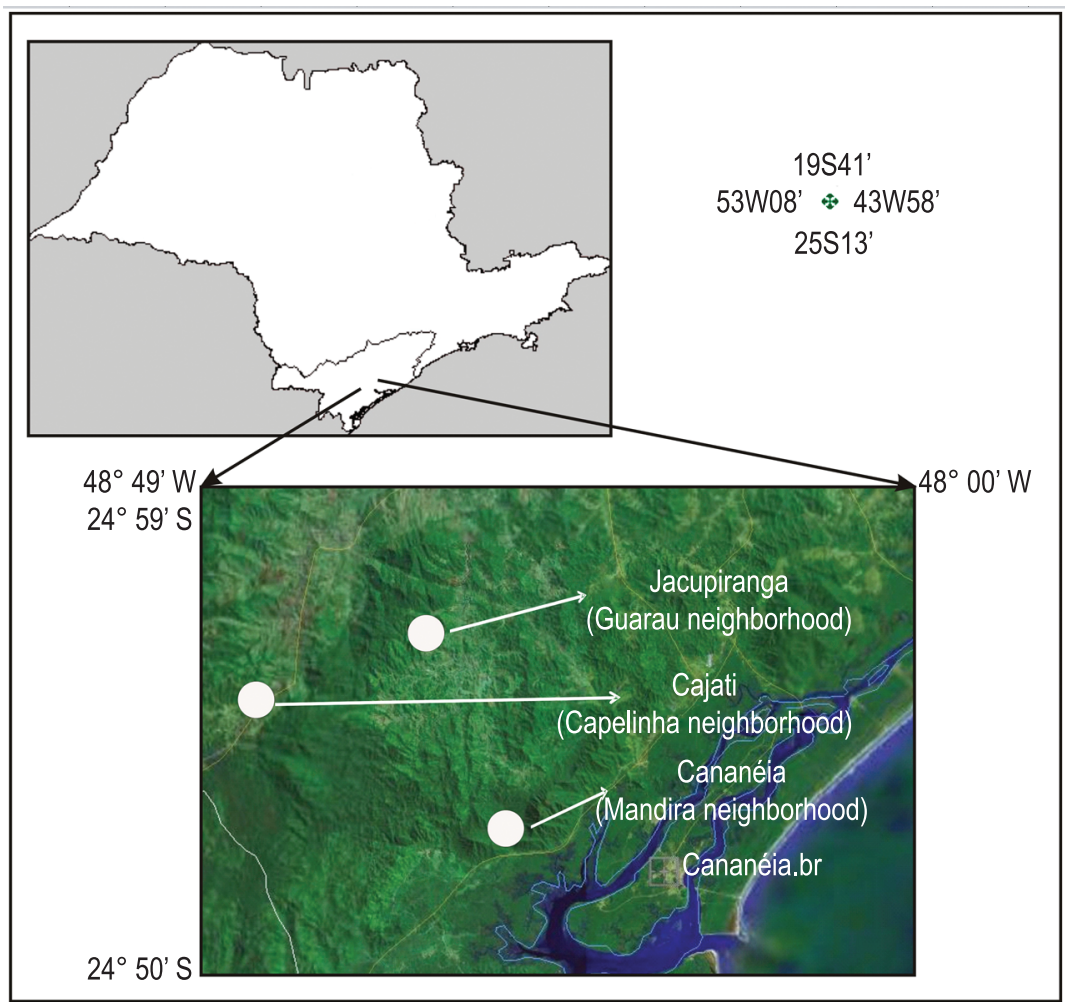

Figure 1. Map of the São Paulo State and satellite image indicating the sampling sites in the region of the Ribeira Valley and South Coast of São Paulo, Brazil (Source: Atlas Biota and Google Earth).

Table 1. General characteristics and localization of the streams.

\begin{tabular}{|c|c|c|c|c|c|c|c|c|}
\hline Municipalities & Streams & $\begin{array}{l}\text { Land } \\
\text { use }\end{array}$ & Coordinates & $\begin{array}{c}\text { Width } \\
\text { (m) }\end{array}$ & $\begin{array}{c}\text { Depth } \\
\text { (cm) }\end{array}$ & $\begin{array}{c}\text { Electric } \\
\text { conductivity } \\
\left(\mu \mathrm{S} . \mathrm{cm}^{-1}\right)\end{array}$ & $\begin{array}{c}\text { Temp. } \\
{ }^{\circ} \mathrm{C}\end{array}$ & $\begin{array}{c}\text { DO } \\
\left(\mathrm{mg} \cdot \mathrm{L}^{-1}\right)\end{array}$ \\
\hline \multirow{2}{*}{ Cajati } & B1 & Banana cultivation & $24^{\circ} 50^{\prime} \mathrm{S} 48^{\circ} 14^{\prime} \mathrm{W}$ & 1.27 & 4.0 & 1.50 & 21,2 & 7.87 \\
\hline & $\mathrm{B} 2$ & Banana cultivation & $24^{\circ} 50^{\prime} \mathrm{S} 48^{\circ} 14^{\prime} \mathrm{W}$ & 0.95 & 8.3 & 0.50 & 21,7 & 10.30 \\
\hline \multirow{2}{*}{ Jacupiranga } & B3 & Banana cultivation & $24^{\circ} 51^{\prime} \mathrm{S} 48^{\circ} 05^{\prime} \mathrm{W}$ & 0.52 & 5.0 & 0.05 & 26,2 & 7.87 \\
\hline & B4 & Banana cultivation & $24^{\circ} 51^{\prime} \mathrm{S} 48^{\circ} 05^{\prime} \mathrm{W}$ & 0.78 & 5.0 & 1.13 & 21,2 & 8.45 \\
\hline \multirow{4}{*}{ Cananéia } & M1 & Riparian vegetation & $25^{\circ} 00^{\prime} \mathrm{S} 48^{\circ} 04^{\prime} \mathrm{W}$ & 2.16 & 14.2 & 0.03 & 19,2 & 9.56 \\
\hline & M2 & Riparian vegetation & $24^{\circ} 57^{\prime}$ S $48^{\circ} 59^{\prime} \mathrm{W}$ & 1.93 & 15.1 & 0.21 & 19,0 & 9.27 \\
\hline & M3 & Riparian vegetation & $24^{\circ} 57^{\prime} \mathrm{S} 48^{\circ} 00^{\prime} \mathrm{W}$ & 1.47 & 13.4 & 0.21 & 19,5 & 9.03 \\
\hline & M4 & Riparian vegetation & $24^{\circ} 58^{\prime} \mathrm{S} 48^{\circ} 00^{\prime} \mathrm{W}$ & 2.71 & 22.1 & 0.24 & 20,4 & 8.20 \\
\hline
\end{tabular}

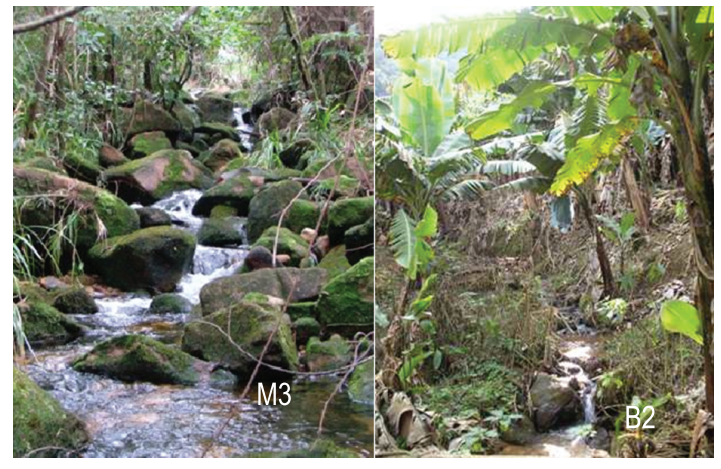

Figure 2. Overview of the streams M3 (Mandira Municipal Reserve - Cananéia) and B2 (neighborhood Capelinha - Cajati).
(Ometto et al., 2000). Moreover, many assessment techniques adopt a multimetric approach using a suite of simple metrics to assess environmental degradation. The strength of this approach lies in its ability to integrate information from the various features of a community to give an overall classification of degradation without losing the information provided by individual metrics (Thorne and Williams, 1997). Consequently, in this study, the stream macroinvertebrates were analysed by the participation of each taxonomic group and the total of organisms collected. In order to evaluate the integrity of each stream, the community characteristics were determined by the 
following metrics: number of families, richness index (Margalef), EPT percentage (Ephemeroptera, Plecoptera and Trichoptera), (\%) of Ephemeroptera, (\%) of Plecoptera and (\%) of Trichoptera.

For the data set (total macroinvertebrates of the 8 streams) a cluster analysis, with UPGMA, using the Simpson similarity measurement was applied to calculate the similarity between streams. Macroinvertebrate families, which showed a close similarity between streams were identified and grouped to a further analysis of similarity (ANOSIM). This was used to detect significant differences between the two groups. For this analysis, $5 \%$ as p-level was considered. The Cluster analysis and the ANOSIM were calculated by using the PAST Program (Version 1.68) (Hammer, 2001).

\section{Results}

About 3,609 individuals were collected, distributed in 57 families, 45 in forested streams and 46 in streams near the banana culture (Table 2). The Chironomidae family (Diptera) was the most abundant, representing $32.8 \%$ of the total fauna, followed by Elmidae (Coleoptera) and Hydropsychidae (Trichoptera) families, which contributed respectively with 19.1 and $4.9 \%$. Those groups were slightly expressive in streams of banana plant cultivation. Baetidae and Leptohyphidae families exhibited high concentration in streams near the banana cultivation areas, while Perlidae, Gripopterygidae, Leptoceridae and Leptophlebiidae families were found in streams of forested ones.

The values of the community index (richness index Margalef $-\mathrm{I}_{\mathrm{Mg}}$, and family richness $-\mathrm{F}$ ) were, in general, higher in the streams with riparian vegetation than in banana cultivation areas (Table 3). The contributions of the Plecoptera, Trichoptera and EPT percentages were higher in preserved streams than in streams near banana cultivation (Table 3 ).

Dissolved oxygen $\left(\mathrm{O}_{2}\right)$ also presented high concentrations in all streams with banana culture and in preserved areas. The values varied from $7.87 \mathrm{mg} . \mathrm{L}^{-1}$ in the $\mathrm{B} 3$ stream to $10.30 \mathrm{mg} . \mathrm{L}^{-1}$ in the B2 stream, both located in areas with banana cultivation. Values of electric conductivity were slightly higher in areas with banana cultivation than in preserved areas. The high value was detected for the B1 stream $\left(0.03 \mu \mathrm{S} . \mathrm{cm}^{-1}\right)$ and low value in M1 stream $\left(1.50 \mu \mathrm{S} . \mathrm{cm}^{-1}\right)$. Concentrations of these components, as well as measurements of other physical and chemical characteristics, are presented in Table 1.
The Cluster analysis applied to the aquatic insects delimited two groups: one grouping the assemblages in streams located in preserved areas (M1, M2, M3 and M4) and the other one in streams in areas adjacent to banana plant cultivation (B1, B2, B3 and B4) (Figure 3). The test of similarity (ANOSIM) applied to the two groups, pointed to significant differences $(\mathrm{p}=0.028)$ between the situations (Figure 3).

\section{Discussion}

Differences between the macroinvertebrate communities in the banana cultivation and preserved streams were also pointed by Castillo et al. (2006), however, the authors related the differences in the community structure to uncertain causes, like the natural variation of the communities and also to pesticide applications.

Some factors like pollution, riparian vegetation and stream order, could have influenced the species richness of the studied streams, as observed by Diniz-Filho et al. (1998) in the central region of Brazil (Goiás State) and by Corbi and TrivinhoStrixino (2008) in streams located in areas with sugarcane cultivation and pastures, without riparian vegetation (Cerrado areas in the state of São Paulo). In this latter study, deforestation of the riparian vegetation was regarded as the principal fact affecting stream macroinvertebrate communities. In contrast, banana plantations promote shading and food resources (litter) for the aquatic macroinvertebrates and also promote a partial covering of the stream bed. In the same way, this type of cultivation, being perennial, dispenses with the need to plough the ground every year for its plantation and thus, is less impactful than other cultures with periodic crops. In this context, our results show some difference from those of other studies obtained from impacted areas, because the streams located in areas with banana cultivation presented higher values of diversity and richness indexes than areas with sugarcane and pasture (Corbi and Trivinho-Strixino, 2008).

Several studies have shown the importance of the riparian canopy for macroinvertebrate communities (Mosisch et al., 2001; Ferreira-Peruquetti and Fonseca-Gessner, 2003; Benstead and Pringle, 2004). Bojsen and Jacobsen (2003) and Kay et al. (2001) showed that the reduction of the riparian canopy causes a decrease in litter detritus on the streambed and an increase in periphyton biomass. In these streams, the macroinvertebrate communities are homogeneous and depauperate, in contrast to 
Table 2. Total number of macroinvertebrates collected in the 8 streams. Legends as Table 1.

\begin{tabular}{|c|c|c|c|c|c|c|c|c|}
\hline & B1 & B2 & B3 & B4 & M1 & M2 & M3 & M4 \\
\hline \multicolumn{9}{|l|}{ Coleoptera } \\
\hline Elmidae & 384 & 111 & 42 & 7 & 64 & 27 & 22 & 31 \\
\hline Hydrophilidae & 13 & 1 & 7 & 33 & 3 & - & - & 6 \\
\hline Staphylinidae & 4 & - & - & - & - & - & - & - \\
\hline Scirtidae & - & 1 & - & - & 3 & 1 & 7 & 2 \\
\hline Dryopidae & 26 & 1 & 3 & - & 4 & - & - & - \\
\hline Hydraenidae & - & - & 1 & - & - & - & - & - \\
\hline Hydroscaphidae & - & - & 1 & - & - & - & - & - \\
\hline Curculionidae & - & - & 1 & 3 & - & - & - & - \\
\hline Lutrochidae & - & - & - & - & 1 & - & - & - \\
\hline Gyrinidae & - & - & - & - & 1 & - & - & - \\
\hline Chrysomelidae & - & - & - & 1 & - & 2 & - & 1 \\
\hline Psephenidae & 3 & 1 & - & - & - & - & - & 2 \\
\hline \multicolumn{9}{|l|}{ Odonata } \\
\hline Libellulidae & 6 & 2 & 3 & 21 & - & - & - & - \\
\hline Megapodagrionidae & 1 & - & - & - & 1 & 1 & 6 & 3 \\
\hline Calopterygidae & - & 1 & - & - & - & - & - & - \\
\hline Gomphidae & - & - & - & - & 2 & 1 & 2 & - \\
\hline Coenagrionidae & - & - & - & 5 & - & 2 & - & 2 \\
\hline \multicolumn{9}{|l|}{ Diptera } \\
\hline Ceratopogonidae & 20 & 4 & 3 & 5 & 3 & 8 & 8 & 8 \\
\hline Empididae & 12 & 6 & - & 2 & - & - & - & 3 \\
\hline Simuliidae & 13 & 2 & 27 & 9 & 2 & 3 & 11 & 10 \\
\hline Tipulidae & 12 & - & - & 1 & 8 & 3 & 7 & 2 \\
\hline Ephydridae & - & - & - & - & - & 1 & - & - \\
\hline Tabanidae & - & - & - & 4 & - & - & - & 1 \\
\hline Stratiomyidae & 2 & - & - & - & - & - & - & - \\
\hline Psychodidae & 1 & - & - & - & - & - & - & - \\
\hline Chironomidae & 548 & 248 & 33 & 49 & 65 & 69 & 132 & 39 \\
\hline \multicolumn{9}{|l|}{ Plecoptera } \\
\hline Gripopterygidae & - & 1 & - & - & 1 & 3 & 51 & 41 \\
\hline Perlidae & - & & - & - & 35 & 7 & 5 & 4 \\
\hline \multicolumn{9}{|l|}{ Ephemeroptera } \\
\hline Baetidae & 2 & 4 & 4 & 121 & 2 & - & 5 & - \\
\hline Leptophebiidae & - & - & - & 7 & 5 & 41 & 41 & 7 \\
\hline Leptohyphidae & - & - & - & 63 & 2 & - & - & - \\
\hline Euthyplociidae & - & - & - & - & 3 & 4 & - & - \\
\hline Caenidae & - & - & - & 41 & - & - & 1 & - \\
\hline \multicolumn{9}{|l|}{ Hemiptera } \\
\hline Gerridae & - & - & 4 & - & 1 & 1 & 15 & - \\
\hline Naucoridae & - & - & - & - & 13 & 6 & 1 & 5 \\
\hline Vellidae & 1 & - & 3 & 2 & 1 & 2 & 3 & 11 \\
\hline \multicolumn{9}{|l|}{ Trichoptera } \\
\hline Hydropsychidae & 41 & 2 & 13 & 67 & 7 & 17 & 21 & 10 \\
\hline Hydroptilidae & 45 & 6 & 4 & 10 & - & 3 & 2 & 1 \\
\hline Leptoceridae & 2 & - & - & - & 59 & 7 & 12 & 3 \\
\hline Polycentropodidae & - & - & - & - & - & 10 & - & - \\
\hline Hydrobiosidae & - & 1 & - & - & - & 1 & 1 & - \\
\hline Helicopsychidae & - & - & - & - & 5 & 13 & 2 & 3 \\
\hline Calamoceratidae & - & - & - & - & 5 & - & 1 & 1 \\
\hline Odontoceridae & - & - & - & - & 8 & 1 & - & 2 \\
\hline Glossosomatidae & 1 & - & - & - & - & - & - & - \\
\hline Xiphocentronidae & 1 & - & - & - & - & - & - & - \\
\hline Philopotamidae & 1 & 1 & - & - & - & 1 & - & - \\
\hline Lepidoptera - Pyralidae & - & 1 & - & 3 & - & 1 & 1 & - \\
\hline Decapoda - Palaeomonidae & 1 & - & - & 4 & 17 & 6 & 13 & 9 \\
\hline Acarina & 1 & - & 2 & 1 & - & 1 & - & - \\
\hline \multicolumn{9}{|l|}{ Oligochaeta } \\
\hline Megadrilos & 7 & 10 & 51 & 17 & - & 3 & 7 & 2 \\
\hline Echytraeidae & - & 1 & 3 & 1 & - & - & - & - \\
\hline Tubificidae & - & - & 3 & 4 & 2 & 14 & 3 & 22 \\
\hline Naididae & 6 & 3 & 1 & 95 & - & - & 2 & 10 \\
\hline Hirudinea - Glossiphoniidae & - & 2 & 1 & 3 & - & - & - & - \\
\hline Turbellaria - Planariidae & - & 1 & 32 & - & 1 & - & - & - \\
\hline Nemertea - Prostoma sp. & 4 & - & 2 & 9 & - & - & - & 1 \\
\hline Total & 1158 & 411 & 244 & 588 & 324 & 260 & 382 & 242 \\
\hline
\end{tabular}


Table 3. Summary of macroinvertebrates community characteristics of the 8 streams. Legends as Table 1.

\begin{tabular}{lcccrrrrr}
\hline \multicolumn{1}{c}{ Community metrics } & B1 & B2 & B3 & B4 & M1 & M2 & M3 & M4 \\
\hline Number of families - F & 27 & 23 & 23 & 28 & 29 & 31 & 27 & 29 \\
EPT Richness & 7 & 6 & 3 & 6 & 11 & 14 & 12 & 11 \\
\% Ephemeroptera & 0.16 & 0.97 & 1.67 & 21.21 & 3.66 & 16.73 & 12.24 & 2.88 \\
\% Plecoptera & 0 & 0.24 & 0 & 0 & 10.98 & 3.72 & 14.58 & 18.52 \\
\% Trichoptera & 7.57 & 2.4 & 6.91 & 7.04 & 25.61 & 19.70 & 10.42 & 8.23 \\
\% EPT & 7.74 & 3.6 & 8.54 & 28.24 & 40.24 & 40.15 & 37.24 & 29.63 \\
Richness index Margalef $(\mathrm{IMg})$ & 3.69 & 3.66 & 4.00 & 4.23 & 4.84 & 5.40 & 4.37 & 5.10 \\
\hline
\end{tabular}

\begin{tabular}{cccccccc}
\multicolumn{1}{c}{ Similarity } \\
0,54 & 0,60 & 0,66 & 0,72 & 0,78 & 0,84 & 0,90 & 0,96 \\
\hline & 1 & 1 & 1 & 1 & 1 & 1 & 1 \\
\hline
\end{tabular}

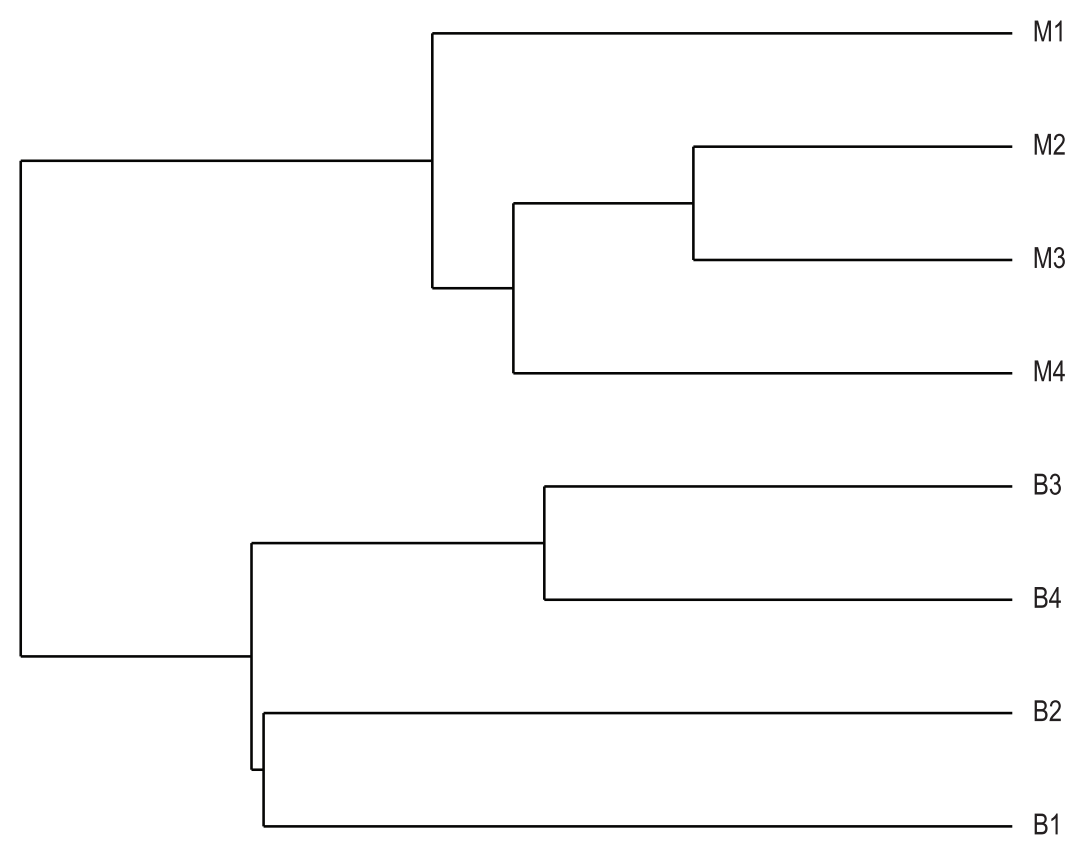

Figure 3. Dendrogram of similarity (Cluster Analysis, using UPGMA with Simpson similarity measurement) applied for the aquatic macroinvertebrates of the 8 streams. Cofenetic correlation $=0.91$. Legends as Table 1 .

those of forested areas. In general, our results also show the importance of the riparian vegetation, which provided a higher taxa richness in the forested streams (M1-M4) when compared to the areas with banana cultivation (B1-B4). Another important aspect was the high participation of the Libelullidae larvae (predator organisms) on the banana cultivation streams. Ferreira-Peruquetti and Fonseca-Gessner (2003) observed similar results in their studies of the Odonata community in the streams with sugarcane culture in the state of São Paulo, and also Corbi and Trivinho-Strixino (2008) observed the same pattern of Libellulidae distribution for streams located in deforested areas in Cerrado streams. Therefore, the occurrence of this group seems to be related to the deforestation of the riparian vegetation and not with banana plant cultivation.

The community index, gave consistent information about the faunistic characteristics and integrity of the 8 streams. The high taxa richness found in the M1, M2, M3 and M4 streams (preserved streams), added to a high ratio of the sensitive taxa (EPT richness, \% of Plecoptera and \% of EPT) clearly showed the importance of riparian vegetation for macroinvertebrate composition. This observation justifies the problem of the deforestation of riparian vegetation in detriment to the growth of banana plant cultivation, which causes a high impact in the stream with the loss of biodiversity. Although located in a deforested area, the banana streams presented a high richness and 
diversity index when compared with the preserved streams. These results are probably related to the remaining portions of banana agricultural activity, in the form of litter from adjacent areas, which could supply the food source for the macroinvertebrates fauna. An important observation was the absence of the Plecoptera in the streams located in areas with banana cultivation. Plecoptera is a sensitive taxa that generally occurs just in preserved streams (Corbi and Trivinho-Strixino, 2008; Lecci and Froehlich, 2007).

The deforestation of riparian vegetation appeared to also be reflected in the high values of temperature observed in the water of the impacted streams (B1 to B4). The higher temperature observed in the deforested streams than in the preserved ones appeared to also reflect in the values of dissolved oxygen in the water measured. The concentrations of cations $(\mathrm{Mg}, \mathrm{Mn}, \mathrm{Na}, \mathrm{K})$ are the components that influence the values of electric conductivity of the streams. Results obtained for the values of electric conductivity, also appeared to be a reflection of agricultural activities. In the deforested streams located in agricultural areas, the input of fertilizers $(\mathrm{N}, \mathrm{P}, \mathrm{K})$ containing metals as micronutrients, probably influenced the high values of this variable in the water as observed for B1 and B4 streams located in areas with banana plant cultivation.

The influence of other factors as environmental variables had not been identified in the analyses. The results pointed to banana cultivation in the adjacent areas as one of the main factors that determine the macroinvertebrate community structure. From the results, we have to consider that the presence of remaining portions of this agricultural activity, as litter from the adjacent areas, appeared to supply, at least in a minor proportion, the food source for the macroinvertebrate fauna of the streams and could contribute to the major richness and diversity of fauna observed in these streams when compared with other agricultural activities.

\section{Acknowledgements}

The authors gratefully acknowledge the fruitful suggestions of Professor Pedro P. Corbi and Dra. Vanessa Colombo Corbi. We thank the state of São Paulo Research Foundation that partially sponsored this work within the Program BIOTA/ FAPESP - The Biodiversity Virtual Institute (www. biota.org.br), process numbers 03/10517-9 and 06/61400-2, and CAPES for fellowships for the first author.

\section{References}

ALLAN, JD., ERICKSON, DL. and FAY, J. 1997. The influence of catchment land use on stream integrity across multiple spatial scales. Freshwater Biology, vol. 37, p. 149-161. http://dx.doi. org/10.1046/j.1365-2427.1997.d01-546.x

AZEVEDO, CAS. and HAMADA, N. 2008. Megaloptera. In FROEHLICH, CG., org. Guia online: Identificação de larvas de Insetos Aquáticos do Estado de São Paulo. Available from: <http://sites. ffclrp.usp.br/aguadoce/index_trico>.

BENSTEAD, JP. and PRINGLE, CM. 2004. Deforestation alters the resource base and biomass of endemic stream insects in eastern Madagascar. Freshwater Biology, vol. 49, p. 490-501. http://dx.doi. org/10.1111/j.1365-2427.2004.01203.x

BIBBY, CJ., COLLAR, NJ., CROSBY, MJ., HEATH, F., IMBODEN, C., JOHNSON, TH., LONG, AJ., STATTERSFIELD, AJ. and THIRGOOG, SJ. 1992. Putting biodiversity on the map: priority areas for global conservation. Cambridge: I.C.B.P. 235 p.

BOJSEN, BH. and JACOBSEN, D. 2003. Effects of deforestation on macroinvertebrate diversity and assemblage structure in Ecuadorian Amazon streams. Archiv Für Hydrobiologie, vol. 158, p. 317-342. http:// dx.doi.org/10.1127/0003-9136/2003/0158-0317

BORGES, AL., OLIVEIRA, AMG. and SOUZA, LS. 1997. Solos, nutrição e adubação. In ALVES, EJ., org. A cultura da banana: aspectos técnicos, socioeconômicos e agroindustriais. Brasília: EmbrapaSPI. p. 197-260.

BRABEC, K., ZAHRÁDKOVÁ, S., NEMEJCOVÁ, D., PARIL, P., KROKES, J. and JARKOVSKÝ, J. 2004. Assessment of organic pollution effect considering differences between lotic and lentic habitats. Hydrobiologia, vol. 516, p. 331-346. http://dx.doi. org/10.1023/B:HYDR.0000025274.47757.85

BRINCKHURST, RO. and MARCHESE, MR. 1991. Guía para la identificación de oligoquetos acuáticos continentales de Sud y Centroamérica. Santo Tome: Asociación Ciencias Naturales del Litoral. 207 p.

CALOR, AR. 2007. Trichoptera. In FROEHLICH, CG., org. Guia on-line: Identificação de larvas de Insetos Aquáticos do Estado de São Paulo. Available from: <http://sites.ffclrp.usp.br/aguadoce/index_trico>.

CASTILlO, LEC., MARTINEZ, E., RUEPERT, C., SAVAGE, C., GILEK, M., PINNOCK, M. and SOLIS, E. 2006. Water quality and macroinvertebrate community response following pesticide applications in a banana plantation, Limon, Costa Rica. Science of the Total Environment, vol. 367, p. 418-432. PMid:16643988. http://dx.doi.org/10.1016/j. scitotenv.2006.02.052

CORBI, JJ. and TRIVINHO-STRIXINO, S. 2006. Influence of taxonomic resolution of stream macroinvertebrate communities on the evaluation 
of different land uses. Acta Limnologica Brasiliensia, vol. 18 , p. 469-475.

CORBI, JJ. and TRIVINHO-STRIXINO, S. 2008. Relationship between sugar cane cultivation and stream macroinvertebrate communities: A study developed in the southeast of Brazil. Brazilian Archives of Biology and Technology, vol. 51, p. 569-579. http:// dx.doi.org/10.1590/S1516-89132008000400015

CORBI, JJ., TRIVINHO-STRIXINO, S. and DOS SANTOS A. 2008. Environmental evaluation of metals in sediments and dragonflies due to sugar cane cultivation in Neotropical streams. Water Air and Soil Pollution, vol. 195, p. 325-333. http://dx.doi. org/10.1007/s11270-008-9749-1

CORBI, JJ., TRIVINHO-STRIXINO, S., DOS SANTOS, A. and DEL GRANDE M. 2006. Environmental diagnostic of metals and organochlorated compounds in streams near sugar cane plantations activity (State of São Paulo, Brazil). Quimica Nova, vol. 29, p. 61-65.

COURTNEY, LA. and CLEMENTS, WH. 2002. Assessing the influence of water and substratum quality on benthic macroinvertebrate communities in metal-pollutes stream: an experimental approach. Freshwater Biology, vol. 47, p. 1766-1778. http:// dx.doi.org/10.1046/j.1365-2427.2002.00896.x

DINIZ-FILHO, JAF., OLIVEIRA, LG. and SILVA, MM. 1998. Explaining the betha diversity of aquatic insects in "Cerrado" streams from Central Brazil using multiple Mantel test. Revista Brasileira de Biologia, vol. 58, p. 223-231.

Embrapa. Mandioca e Fruticultura Tropical. 2007. Perguntas e Respostas: Banana. Available from: <http:// www.cnpmf.embrapa.br/index.php?p=perguntas_e respostas-banana.php\#pos>. Acess in: 19 fev. 2007.

FERREIRA-PERUQUETTI, P. and FONSECAGESSNER, AA. 2003. Comunidade de Odonata (Insecta) em áreas naturais de Cerrado e monocultura no nordeste do Estado de São Paulo, Brasil: relação entre uso do solo e a riqueza faunística. Revista Brasileira de Zoologia, vol. 20, no. 2, p. 219-224. http://dx.doi.org/10.1590/S010181752003000200008

FONTOURA, AP. 1985. Manual de vigilância da qualidade das águas superficiais: avaliação biológica da qualidade da água. Porto: Instituto de zoologia "Dr. Augusto Nobre"; Faculdade de Ciências; Universidade do Porto. 38 p.

HAMMER, O., HARPER, DAT. and RYAN, PD. 2001. PAST: Paleontological Statistics software package for education and data analysis. Paleontologia Eletronica, vol. 4, no. 1, p. 1-9.

KAY, WR., HALSE, SA., SCANLON, MD. and SMITH, MJ. 2001. Distribution and environmental tolerances of aquatic macroinvertebrate families in the agricultural zone of southwestern Australia. Journal of the North American Benthological Society, vol. 20, p. 182-199. http://dx.doi.org/10.2307/1468314

KLEINE, P. and TRIVINHO-STRIXINO, S. 2005. Chironomidae and other aquatic macroinvertebrates of a first order stream: community response after habitat fragmentation. Acta Limnologica Brasiliensia, vol. 17, p. 81-90.

LECCI, LS. and FROEHLICH, CG. 2007. Plecoptera. In FROEHLICH, CG., org. Guia on-line: Identificação de larvas de Insetos Aquáticos do Estado de Sáo Paulo. Available from: $<$ http://sites.ffclrp.usp.br/aguadoce/ index_trico $>$.

LEGENDRE, P., DALE, MT., FORTIN, MJ., GUREVITCH, J., HOHN, M. and MYERS D. 2002. The consequences of spatial structure for design and analysis of ecological field surveys. Ecography, vol. 25, p. 601-615. http://dx.doi.org/10.1034/ j.1600-0587.2002.250508.x

MARIANO, R. and FROEHLICH, CG. 2007. Ephemeroptera. In FROEHLICH, CG., org. Guia on-line: Identificação de larvas de Insetos Aquáticos do Estado de São Paulo. Available from: <http://sites. ffclrp.usp.br/aguadoce/index_trico >.

MERRITT, RW. and CUMMINS KW. 1996. An introduction to aquatic insects of North America. Duduque: Kendall-Hunt. 448 p.

MOSISCH, TD., BUNN, SE. and DAVIES PM. 2001. The relative importance of shading and nutrients on algal production in subtropical streams. Freshwater Biology, vol. 46, p. 1269-1278. http://dx.doi. org/10.1046/j.1365-2427.2001.00747.x

MYERS, N., MITTERMEIER, RA., MITTERMEIER, CG., FONSECA, GAB. and KENT, J. 2000. Biodiversity hotspots for conservation priorities. Nature, vol. 403, p. 853-858. PMid:10706275. http://dx.doi.org/10.1038/35002501

NEVES, EM., DAYOUB, M. and DRAGONE, DS. 2002. Análise da demanda por defensivos pela fruticultura brasileira. Revista Brasileira de Fruticultura, vol. 24, p. 694-696. http://dx.doi. org/10.1590/S0100-29452002000300031

OMETTO, JPHB., MARTINELLI, LA., BALLISTER, MV, GESSNER, A., KRISCHE, AV. and VICTORIA, RL. 2000. The effects of land use on water chemistry and macroinvertebrates rates in two streams of the Piracicaba river basin South-east Brazil. Freshwater Biology, vol. 44, p. 327-337. http://dx.doi. org/10.1046/j.1365-2427.2000.00557.x

PINHO, LC. 2008. Diptera. In FROEHLICH, CG., org. Guia on-line: Identificação de larvas de Insetos Aquáticos do Estado de São Paulo. Available from: $<$ http://sites.ffclrp.usp.br/aguadoce/index_trico $>$.

PRINGLE, CM., FREEMAN, MC. and FREEMAN, BJ. 2000. Regional effects of hydrologic alterations on riverine macrobiota in the New World: tropicaltemperate comparisons. BioScience, vol. 50, 
p. 807-823. http://dx.doi.org/10.1641/00063568(2000)050[0807:REOHAO]2.0.CO;2

RICHARDS, C. and HOST, GE. 1993. Identification of predominant environmental factors structuring stream macroinvertebrate communities within a large agricultural catchment. Freshwater Biology, vol. 29, p. 285-294.

ROQUE, FO. and TRIVINHO-STRIXINO, S. 2001. Benthic macroinvertebrates in mesohabitats of different spatial dimensions in a first order stream (São Carlos - SP). Acta Limnologica Brasiliensia, vol. 13, p. 69-77

RUSSEL, BR. and WARD, JV. 1988. Influence of regulation on environmental conditions and the macroinvertebrate community in the Colorado River. Regulated Rivers, vol. 2, p. 597-618. http://dx.doi. org/10.1002/rrr.3450020505

SOUZA, LOI., COSTA, JM. and OLDRINI, BB. 2007. Odonata. In FROEHLICH, CG., org. Guia on-line: Identificaçáo de larvas de Insetos Aquáticos do Estado de São Paulo. Available from: <http://sites.ffclrp.usp. br/aguadoce/index_trico $>$.
THORNE, RSTJ. and WILLIAMS, WP. 1997. The response of benthic macroinvertebrates to pollution in developing countries: a multimetric system of bioassessment. Freshwater Biology, vol. 37, p. 671-686. http://dx.doi.org/10.1046/j.13652427.1997.00181.x

TOWNSEND, CR., DOWNES, BJ., PEACOCK, K. and ARBUCKLE CJ. 2004. Scale and detection of land-use effects on morphology, vegetation and macroinvertebrate communities of grassland streams. Freshwater Biology, vol. 49, p. 448-462. http://dx.doi. org/10.1111/j.1365-2427.2004.01192.x

WILHM, JL. 1967. Comparison of some diversity indices applied to populations of benthic macroinvertebrates in stream receiving organic wastes. Journal WPCF, vol. 39, p. 1671-1682.

WOOD, PJ. and ARMITAGE, PD. 1997. Biological effects of fine sediment in the lotic environment. Environment Management, vol. 21, p. 203-217. PMid:9008071. http://dx.doi.org/10.1007/ s002679900019

Received: 04 August 2011 Accepted: 02 April 2012 